\title{
Бухаров М.А. \\ Профилактика правонарушений и преступлений несовершеннолетних через их патриотическое воспитание
}

Академия управления МВД России

(Россия, Москва)

doi:10.18411/spc-20-01-2018-01

idsp: 000001:spc-20-01-2018-01

Совершенствование действующей системы профилактики преступлений и правонарушений среди несовершеннолетних требует поиска новых способов реализации и методов ее развития.

Органами внутренних дел совместно с учреждениями, входящими в систему профилактики безнадзорности и правонарушений несовершеннолетних, разрабатываются формы и методы предупредительной работы в образовательных учреждениях, по месту жительства и на иных объектах массового присутствия несовершеннолетних.

В рамках реализации государственной программы «Патриотическое воспитание граждан Российской Федерации на 2016-2020 годы», утвержденного постановлением Правительства Российской Федерации от 30.12.2015 № 1493, сотрудниками ОВД в образовательных учреждениях проводится работа по патриотическому воспитанию учащихся.

Эффективным инструментом воспитания гражданственности, патриотизма, здорового образа жизни для детей и подростков является обучение в кадетских школах и классах.

Кадетские общеобразовательные организации разрабатывают новое содержание образования и новые технологии обучения, восполняют необходимость гражданствености, целенаправленно занимаются военно-патриотическим воспитанием, создают оптимальные условия для раскрытия и развития индивидуальных особенностей каждого обучающегося, формируют основы для подготовки несовершеннолетних граждан к военной службе, осуществляют профилизацию общего образования в старших классах.

В настоящее время в Российской Федерации действуют все больше и больше кадетских школ, профильных классов правоохранительной направленности, кроме того, открываются классы с углубленным изучением предметов военно-патриотической и оборонно-спортивной направленности

МВД России и его структурные подразделения оказывают всестороннюю помощь и поддержку образовательным учреждениям, реализующим программы кадетского образования правоохранительной направленности. Сотрудники подразделений по делам несовершеннолетних проводят с учащимися занятия по правовой подготовке, организуют для учащихся экскурсии в подразделения МВД, оказывают содействие в организации и проведении торжественного принятия присяги кадетами младших классов, а также военно-спортивной игры «Зарница».

Действенным механизмом воспитания у детей гражданственности, нравственности, профилактики является деятельность правоохранительных отрядов.

Отряды правоохранительной направленности действуют в рамках Положений об отрядах, утвержденных в образовательных учреждениях, и составленных на основе примерных положений.

Основными задачами деятельности отрядов являются: 
1) ориентация подростков на правоохранительные специальности; повышение правовой грамотности учащихся;

2) воспитание сознательного соблюдения учащимися правил поведения и нетерпимого отношения к лицам, нарушающих их;

3) разъяснение среди подростков правил поведения учащихся на улицах и в общественных местах;

4) индивидуальная работа с детьми и подростками, совершающими правонарушения.

Особое внимание обращает на себя деятельность отрядов Юных инспекторов движения. В настоящее время на базе образовательных учреждений области действуют центры по профилактике детского дорожно-транспортного травматизма, автогородки, площадки по изучению ПБДД,

Вопросы патриотического воспитания несовершеннолетних приобрели системный характер и реализуются сотрудниками ОВД в повседневной деятельности.

Особое внимание уделено повышению престижа службы органов внутренних дел. В этих целях в подразделениях по делам несовершеннолетних проводятся дни открытых дверей. Молодежным объединениям и клубам военно-патриотической направленности предоставляется учебно-материальная база, оказывается методическая помощь в обучении и проведении мероприятий патриотической направленности, организуются экскурсии в музей МВД, выставки вооружения и боевой техники, показательные выступления сотрудниками $\mathrm{OMOH}$, проводятся занятия по рукопашному бою, спортивные мероприятия.

Традиционно в преддверии Дня защитника Отечества, Дня Победы сотрудниками ОВД в образовательных учреждениях проводятся «Уроки мужества»с участием ветеранов Великой Отечественной войны, ветеранов ОВД, участников боевых действий.

В рамках патриотического воспитания, сотрудниками ОВД ежегодно в День России проводится профилактическая акция «Я - гражданин России». В рамках которой подросткам, достигшим возраста 14 лет, в торжественной обстановке вручаются паспорта. Традиционно в акции принимают участие представители ОВД, представители комиссий по делам несовершеннолетних и защите их прав, отдела образования, воинской части и ветераны.

В ходе реализации мероприятий по патриотическому воспитанию сотрудники органов внутренних дел тесно взаимодействуют с муниципальными органами власти, управлениями образования и молодежной политики.

Регулярность и целенаправленность и непрерывность указанных мер позволит, в большей части, предотвращать преступления и правонарушения совершаемые несовершеннолетними, вовлечь их в общественно полезную деятельность и существенным образом повлиять на подростковую преступность.

$$
\text { *** }
$$

1. Об основных гарантиях прав ребенка в Российской Федерации: федер. закон от 24 июля 1998 г. № 124-Ф3 (ред. от 28.12.2016). [Электронный ресурс]. Доступ из справ.-правовой системы «КонсультантПлюс».

2. О государственной программе «Патриотическое воспитание граждан Российской Федерации на 2016-2020 годы» Постановлением Правительства Российской Федерации от 30.12.2015 № 1493

3. Об утверждении Примерного положения о комиссиях по делам несовершеннолетних и защите их прав: постановление Правительства РФ от 6 ноября 2013 г. № 995

4. Васильев Ф.П., Иванов В.В. Административно-правовая защита детей от неправомерной информации // Административное право и процесс. 2012. № 5. С. 46. 